Primljen / Received: 13.4.2017. Ispravljen / Corrected: 7.11.2017.

Prihvaćen / Accepted: 4.7.2018. Dostupno online / Available online: 10.8.2018.

\title{
Geotechnical characterization and bearing capacity performance of blast furnace slag
}

Authors:

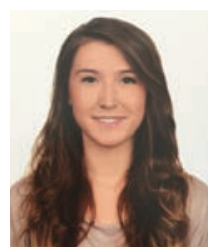

Inci Develioğlu, MCE

İzmir Katip Çelebi University, Turkey Faculty of Engineering and Architecture Department of Civil Engineering inci.develioglu@ikc.edu.tr

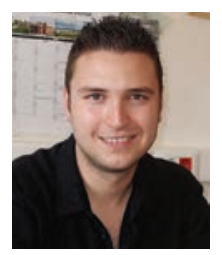

Assist.Prof. Hasan Firat Pulat, PhD. CE İzmir Katip Çelebi University, Turkey Faculty of Engineering and Architecture Department of Civil Engineering hfirat.pulat@ikc.edu.tr
Scientific Paper

\author{
Inci Develioğlu, Hasan Firat Pulat
}

\section{Geotechnical characterization and bearing capacity performance of blast furnace slag}

Geotechnical properties and factors affecting bearing capacity of Blast Furnace Slag (BFS) are analysed in this study. The California Bearing Ratio (CBR) tests were performed using fine and coarse grained BFS samples. The CBR test samples were prepared using standard and modified compaction energies. To examine the effect of pore fluid on bearing capacity, samples were prepared with tap and sea water. Test results show that fine grained samples have higher CBR values compared to coarse grained samples. Compaction energy exerted the greatest influence on CBR results and higher CBR values were obtained for samples prepared and cured with sea water.

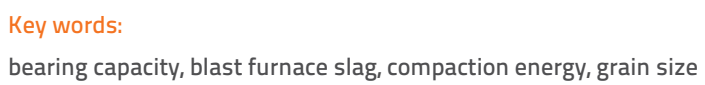

Znanstveni rad

Inci Develioğlu, Hasan Firat Pulat

\section{Geotehnička svojstva i nosivost zgure iz visoke peći}

U radu su analizirana geotehnička svojstva i nosivost zgure iz visoke peći. Ispitivanja CBR vrijednosti provedena su sa sitnozrnim i krupnozrnim uzorcima zgure iz visokih peći. Uzorci za ispitivanjeCBR-a pripremljeni su standardnim i modificiranim energijama zbijanja. Za ispitivanje učinka fluida u porama na nosivost, pripremljeni su uzorci s vodom iz vodovoda i s morskom vodom. Rezultati ispitivanja pokazali su da sitnozrni uzorci imaju većeCBR vrijednosti u usporedbi s krupnozrnim, a energija zbijanja je bila parametar koji je najviše utjecao na vrijednosti CBR-a. Veće CBR vrijednosti pripadale su uzorcima koji su pripremljeni i njegovani s morskom vodom.

Ključne riječi:

zgura iz visoke peći, nosivost, energija zbijanja, veličina zrna

Wissenschaftlicher Artikel

Inci Develioğlu, Hasan Firat Pulat

\section{Geotechnische Eigenschaften und Tragfähigkeit der Schlacke aus dem Hochofen}

In der Abhandlung werden die geotechnischen Eigenschaften und die Tragfähigkeit der Schlacke aus dem Hochofen analysiert. Die Untersuchungen des CBR-Wertes wurden mit feinkörnigen und grobkörnigen Schlackeproben aus dem Hochofen durchgeführt. Die Proben aus der CBR-Untersuchung wurden durch standardmäßige und modifizierte Verdichtungsenergien vorbereitet. Für die Untersuchung der Wirkung von Fluid in den Poren auf die Tragfähigkeit wurden die Proben mit Wasser aus der Wasserleitung und mit Meerwasser vorbereitet. Die Untersuchungsergebnisse zeigten, dass die feinkörnigen Proben einen höheren CBR-Wert im Vergleich zu den grobkörnigen aufweisen, und die Verdichtungsenergie war der Parameter, der sich am meisten auf die CBR-Werte auswirkte. Die höheren CBR-Werte gehörten zu den Proben, die mit Meerwasser vorbereitet und gepflegt wurden. 


\section{Introduction}

Adverse effects of construction materials, such as greenhouse effects and effects of $\mathrm{CO}_{2}$ gas emissions, have led researchers to look for less harmful alternative materials [1-5]. The blast furnace slag (BFS) is one of the re-usable waste materials that can be used in various civil engineering applications, such as in road pavement construction, soil improvement, and ready mixed concrete manufacturing [6-10]. Buddhdev and Varia (2014) examined chemical and physical properties of BFS use as fine aggregate in pavement concrete manufacturing. The reported specific gravity values of BFS ranged from 2.46 to 3.04 . Average mass per unit volume amounted to $1.48 \mathrm{~kg} / \mathrm{cm}^{3}$ and $1.66 \mathrm{~kg} /$ $\mathrm{cm}^{3}$ for loose and compacted samples, respectively. Researchers reported that BFS can be used as fine aggregate in pavement concrete manufacturing. The BFS is also used as a ground improvement material especially for expansive clay soils [11]. Cokca et al. (2009) used granulated blast furnace slag (GBFS) and GBFS-cement (GBFSC) to reduce excessive swelling potential of expansive clay. GBFS and GBFSC were added to soil sample in the proportions of $5-25 \%$. In this study, the grain size distribution, consistency limits, rate of swell, and swelling percentage, were determined for various mixtures. Particle analyses have shown that clay fractions decreased and silt fractions increased with the addition of GBFS and GBFSC. While plasticity index and swell percentage decreased, specific gravity increased for all GBFS and GBFSC additions. Researchers reported that, after taking environmental factors into consideration, $15 \% \mathrm{BFS}$ addition is the best choice [12]. Sivrikaya et al. (2014) examined potential use of granulated blast furnace slag (GBFS) in low plasticity Kolsuz clay and high plasticity bentonite clay stabilizations. Samples were prepared in the proportions of $5 \%, 10 \%, 20$ $\%, 30 \%$, and $50 \%$, and the unit weights, Atterberg limits, and compaction parameters were determined. The plastic limit of the stabilized Kolsuz clay increased from $19 \%$ to $21 \%$, while the liquid limit decreased from $28 \%$ to $21 \%(P I=0)$. For bentonite clay, plastic limit of a stabilized sample increased from $32 \%$ to $55 \%$, and liquid limit decreased from $212 \%$ to $147 \%$. Also, the plasticity index decreased from $180 \%$ to $92 \%$. Compaction test results showed that the optimum water content of stabilized samples ranged from $14.2 \%$ to $14.9 \%$, and the maximum dry unit weight ranged from 17.6 to $18.2 \mathrm{kN} / \mathrm{m}^{3}$ for Kolsuz clay. The optimum water content of stabilized samples ranged from 16.8 $\%$ to $17.5 \%$, and the maximum dry unit weights ranged from 15.65 to $16.41 \mathrm{kN} / \mathrm{m}^{3}$ for bentonite clay [13]. O'Kelly investigated geotechnical engineering properties of two granulated BFS [7]. The specific gravities, maximum dry densities, internal friction angles, hydraulic conductivities, $\mathrm{pH}$, and California Bearing Ratios (CBR) of BFS samples were determined. The BFS samples were classified as well graded gravely sands according to USCS. The specific gravities were 2.41 and $2.67, \mathrm{pH}$ was 12 , and dry densities were 1.34 and $1.47 \mathrm{t} / \mathrm{m}^{3}$. The angle of internal friction values ranged between $39^{\circ}$ and $40^{\circ}$. Hydraulic conductivities varied from 1.8 to $3.410^{-3} \mathrm{~m} / \mathrm{s}$. CBR values amounted from 16.0 to 31.1. This researcher emphasized that BFS is suitable for pavement and highway embankment construction [7].

Previous studies have revealed an increase in CBR within the increment of soil suction or within the decrement of saturation degree [14-19]. Similar to this opinion, it is widely accepted that CBR values are extremely related to the degree of compaction and water content $[20,21]$. Based on this information, bearing capacity of BFS has been examined to gain further experimental data in order to clarify the dependence of CBR on various engineering materials.

Laboratory experiments were conducted in this study to determine geotechnical properties and bearing capacity of BFS. Geotechnical index properties of BFS were determined. $X$ - ray diffraction (XRD) analyses were conducted to determine chemical composition of samples and then the effects of different parameters on the bearing capacity of BFS were investigated. The fine and coarse grained samples were subjected to CBR testing. Test samples were prepared at an optimum water content using standard and modified compaction energies. Then the samples were tested either immediately or after 96 hours of curing. Sea and tap water was used as pore fluid in order to examine the pore fluid effects on the bearing capacity and chemical composition of BFS.

\section{Material and methods}

BFS is the byproduct material that is obtained during steel production in blast furnace. BFS is granulated by shock cooling and grinded afterwards. BFS has a granulated structure once it is shock cooled with water $[7,12]$. The bulk density of BFS is less than that of traditional stone because it has multi-hole structure and composition [22]. The composition and structure of BFS are shown in Figure 1.
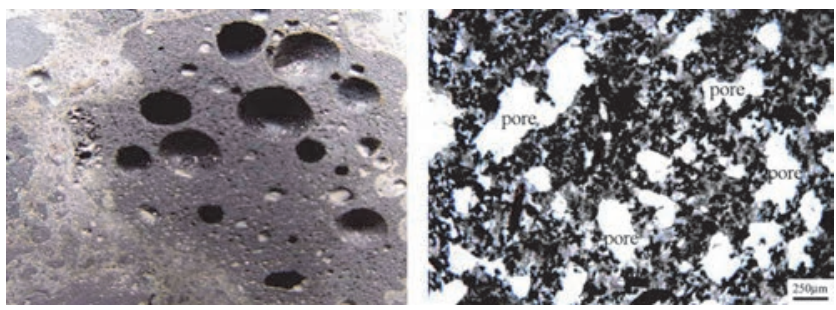

Figure 1. Composition and structure of BFS [22]

Typical constituents of BFS are lime ( $\mathrm{CaO})$, magnesium oxide $(\mathrm{MgO})$, silica $\left(\mathrm{SiO}_{2}\right)$, alumina $\left(\mathrm{Al}_{2} \mathrm{O}_{3}\right)$, sulphur $(\mathrm{S})$, iron oxide $\left(\mathrm{Fe}_{2} \mathrm{O}_{3}\right)$, and manganese oxide ( $\mathrm{MnO}$ ) [7]. In this study, X-ray diffraction (XRD) analyses were conducted for the pure (natural) sample and BFS samples mixed with seawater and tap water. The BFS material was obtained from Özerdem Demir Contracting Construction Marketing Industry and Trade Limited Company located in Aliaga, İzmir, Turkey.

The particles larger than $9.5 \mathrm{~mm}$ were removed according to particle size restrictions defined in ASTM standards. The BFS materials were divided into two parts, and then engineering 
properties of fine grained $\left(D_{\max }=4.75 \mathrm{~mm}\right)$ and coarse grained $\left(D_{\max }=9.50 \mathrm{~mm}\right)$ samples were determined in the soil mechanics laboratory (Figure 2).

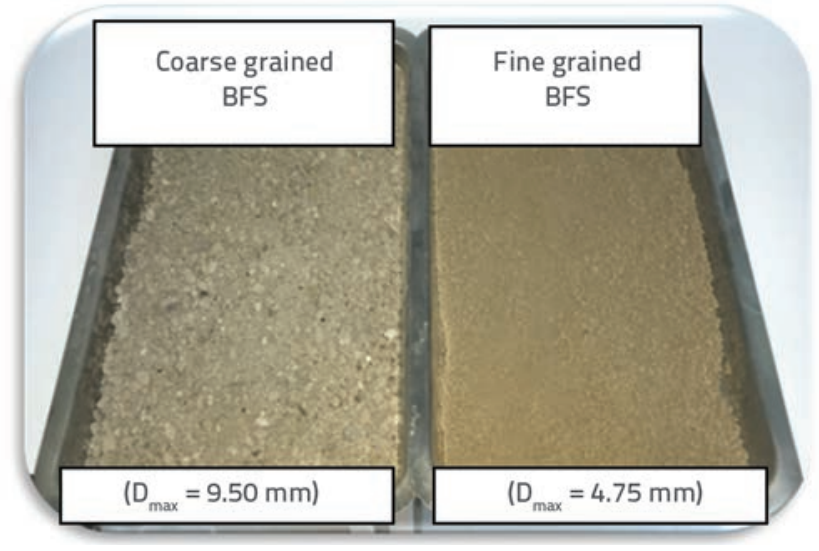

Figure 2. Coarse and fine grained BFS samples

The particle size distribution was determined according to ASTM-D422-07 [23]. Both coarse and fine grained BFS samples were dried in oven and then washed through No. 200 (0.075 mm) sieve, until clear water came out. The material retained on the sieve was collected and dried, and then the dry sieve analysis was performed. The plastic and liquid limits, also known as Atterberg limits, were determined according to ASTM-D4318-10 [24]. The fall cone test method was used to specify liquid limits of fine and coarse grained samples. The coarse and fine grained samples were classified by means of particle size distribution graphs, and the consistency limit values were determined according to ASTM-D2487-11 [25]. The specific gravity of BFS was determined using a $500 \mathrm{ml}$ glass pycnometer and a vacuum pump according to ASTM D854-14 [26].

The $\mathrm{pH}$ values of fine and coarse grained BFS samples were determined according to a method proposed by Kocasoy (1994) [27]. The suspension was formed by mixing a $50 \mathrm{~g}$ BFS sample and $125 \mathrm{ml}$ of distilled water. After $24 \mathrm{~h}$ the $\mathrm{pH}$ measurement was made using a digital $\mathrm{pH}$ meter. Each test was performed two times to check repeatability of measurements. Standard and Modified Proctor (SP and MP) tests were performed according to ASTM D698-07 and ASTM D1557-12e1 in order to determine the optimum moisture content and maximum dry density [28, 29].

The CBR test is an empirical penetration test that is generally used for aggregates and construction materials. This method can be applied to most types of soil ranging from heavy clay to medium size gravel material. The CBR test gives direct bearing capacity and indirect shear strength results. Former studies have shown that test results are extremely dependent on the level of compaction and moisture content $[20,21]$. The CBR tests were conducted according to ASTM D1883-16 [30]. The CBR test specimens were prepared at optimum moisture content obtained from Standard and Modified Proctor tests. Moreover, the investigation of moisture condition effects on bearing capacity was conducted according to two distinct scenarios. In the first scenario, the CBR test was performed immediately after sample preparation.

In the second scenario, after the specimen was prepared at optimum water content, it was cured for 96 hours under a 4.54 kg surcharge, and then the CBR test was conducted (Figure 3).

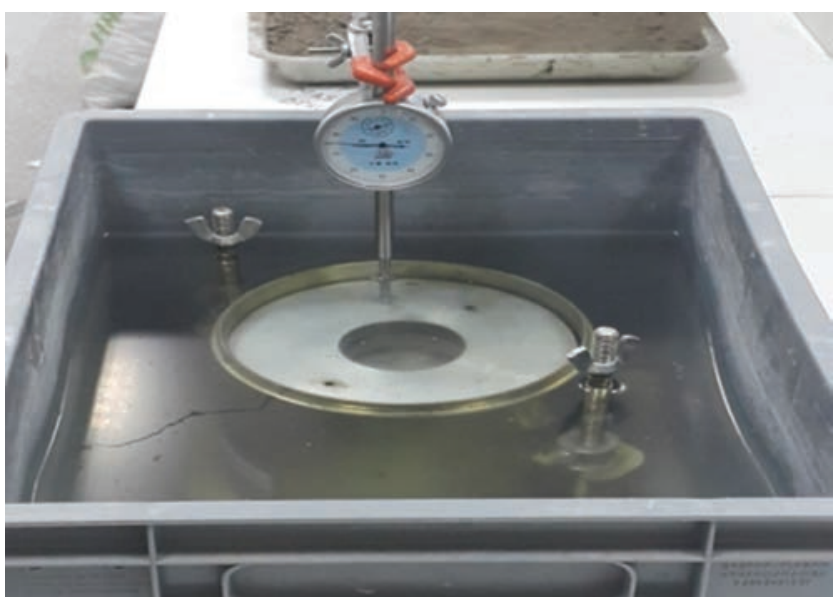

Figure 3. Cured CBR test sample

The applied stress levels were obtained for pre-determined penetration points with $1.27 \mathrm{~mm} / \mathrm{min}$ standard loading rate based on CBR test conducted according to ASTM-D1883-16 [30]. The maximum capacity of the laboratory CBR test apparatus is $45 \mathrm{kN}$. In order to determine the CBR value, the corrected stress value corresponding to $0.200 "$ " $(5.08 \mathrm{~mm})$ penetration in the stress-penetration curve was divided to the standard stresses of 1500 psi (10 MPa) and multiplied by 100 . In order to investigate the pore fluid effects on bearing capacity performance, sea and tap waters were used in sample preparation and curing processes. The ion chromatography analysis was conducted using the GP50 Dionex IC instrument, and the ionic composition of natural seawater was identified. In order to determine chemical composition of BFS, $X$-ray diffraction (XRD) analyses were conducted for the pure (natural) sample and BFS samples mixed with seawater and tap water. Firstly, samples were sieved through No. 200 (0.075 mm) sieve. The pure (natural) sample was directly tested.
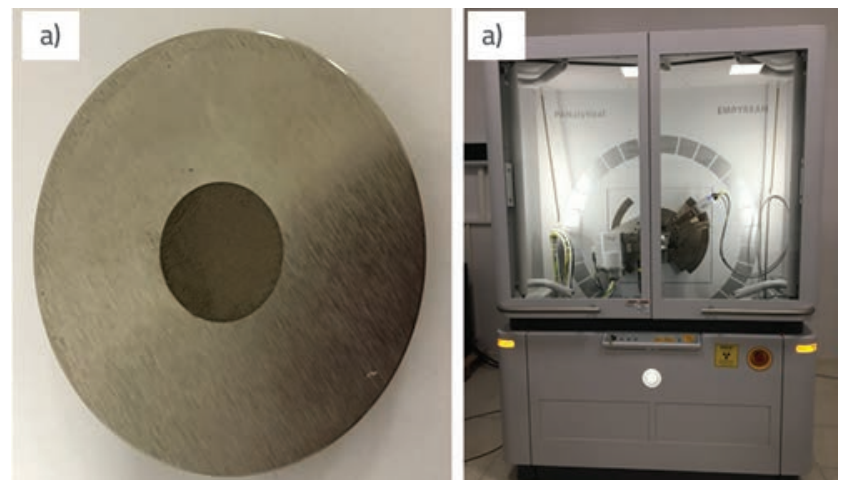

Figure 4. a) Specimen placed on sample plate; b) XRD device 
Other samples were mixed with tap and sea water at an optimum moisture content and then dried in oven. The analysis was conducted at the central research laboratory of the Izmir Katip Çelebi University. The specimen was placed on the sample plate with small bumps (Figure 4.a). Then the analysis was performed using the PANalytical brand Empyrean model XRD device (Figure 4.b).

\section{Results and discussion}

The grain size distribution of fine and coarse grained BFS samples is shown in Figure 5. It can be seen from the same figure that particles smaller than $0.075 \mathrm{~mm}$ constitute a very small portion of the total quantity of the two samples.

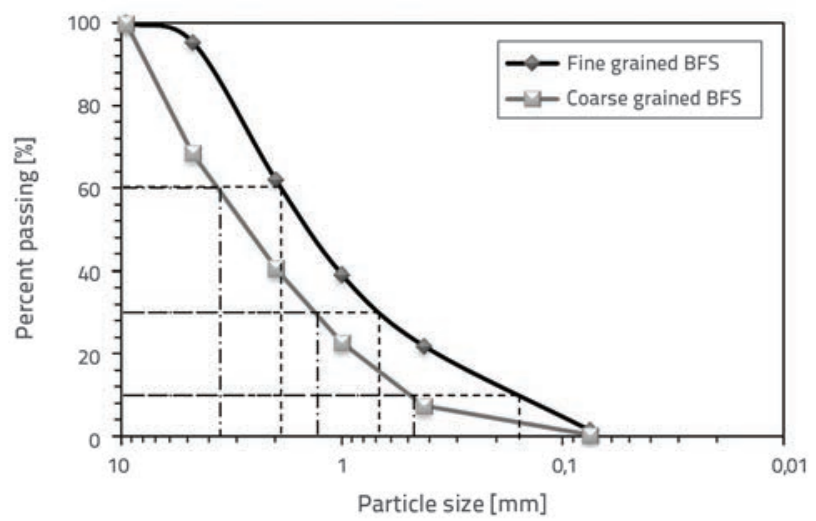

Figure 5. Grain size distribution of fine and coarse grained BFS samples

The obtained geotechnical index properties of BFS samples are summarized in Table 1. Classification was made depending on the results of grain size distribution analysis and Atterberg's limits, according to the Unified Soil Classification System (USCS) [31].

Table 1. Geotechnical index properties of BFS samples

\begin{tabular}{|l|c|c|}
\hline Properties & Fine BFS & Coarse BFS \\
\hline Liquid limit, $\mathrm{w}_{\mathrm{L}}[\%]$ & 34.1 & 34.1 \\
\hline Plastic limit, $\mathrm{w}_{\mathrm{p}}[\%]$ & $\mathrm{NP}$ & $\mathrm{NP}$ \\
\hline Natural water content, $\mathrm{w}_{\mathrm{n}}[\%]$ & 7.9 & 7.9 \\
\hline USCS & SW & SW \\
\hline pH & 9.8 & 10.2 \\
\hline Specific gravity, $\mathrm{G}_{\mathrm{s}}$ & 3.07 & 3.35 \\
\hline
\end{tabular}

Laboratory test results show that an average specific gravity value of BFS is 3.21 . The plastic limit test shows that BFS is a non plastic (NP) material. Compaction curves of fine and coarse grained samples obtained from Standard and Modified Proctor tests are shown in Figure 6.

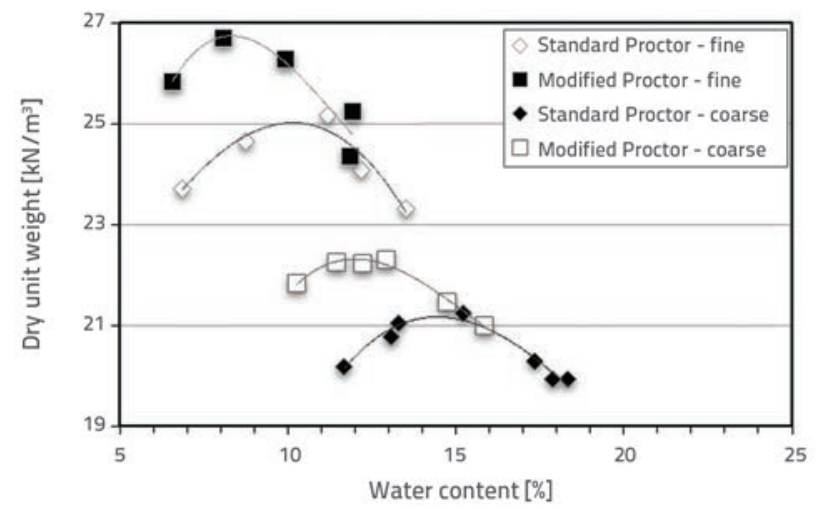

Figure 6. Compaction curves for fine and coarse grained BFS samples

Figure 6 shows that the optimum moisture content of fine and coarse grained BFS samples ranges between $8.3 \%$ and 14.8 $\%$ for Standard and Modified Compaction energy, respectively. The maximum dry unit weight of fine and coarse grained BFS samples ranges between 21.2 and $26.3 \mathrm{kN} / \mathrm{m}^{3}$ for Standard and Modified Compaction energy, respectively. The optimum moisture content values and maximum dry unit weight values are summarized in Table 2.

The ion chromatography analysis was conducted with a GP50 Dionex IC instrument, and the ionic composition of natural seawater was identified (Table 3).

Table 2. Compaction tests results of fine and coarse grained BFS samples

\begin{tabular}{|c|c|c|c|}
\hline Material & Test type & $\gamma_{\text {d.max }}\left[\mathrm{kN} / \mathrm{m}^{3}\right]$ & $\mathbf{w}_{\text {opt }}[\%]$ \\
\hline \multirow{2}{*}{ Fine slag } & Standard Proctor & 25.0 & 10.2 \\
\cline { 2 - 4 } & Modified Proctor & 26.3 & 8.3 \\
\hline \multirow{2}{*}{ Coarse slag } & Standard Proctor & 21.2 & 14.8 \\
\cline { 2 - 4 } & Modified Proctor & 22.3 & 12.0 \\
\hline
\end{tabular}

X-ray diffraction (XRD) analyses were conducted for the pure (natural) sample and BFS samples mixed with seawater and tap water. The chemical component ratios of the three samples are summarized in Table 4.

Calcium carbonate with low strength was quite high in natural and tap water samples. On the other hand, the BFS sample mixed with seawater exhibited a high calcite ratio. It is considered that calcium carbonate transformed to calcite by sea water effect [32]. The XRD spectrum of natural BFS sample is given in Figure 7.

Table 3. Ion chromatography analysis results for seawater in ppm (ppm = parts-per-million, $\mathbf{1 0}^{-6}$ )

\begin{tabular}{|c|c|c|c|c|c|c|c|c|}
\hline & $\mathbf{C a}(\mathbf{p p m})$ & $\mathbf{N a}(\mathbf{p p m})$ & $\mathbf{K}(\mathbf{p p m})$ & $\mathbf{M g}(\mathbf{p p m})$ & $\mathbf{C l}(\mathbf{p p m})$ & $\mathbf{B r}(\mathbf{p p m})$ & $\mathbf{S O}_{4}^{-2}(\mathbf{p p m})$ & $\mathbf{S r}(\mathbf{p p m})$ \\
\hline Seawater & 486.6 & 12301.5 & 487.7 & 1481.4 & 23852.0 & 70.3 & 3115.2 & 15.5 \\
\hline
\end{tabular}


Table 4. XRD test results of BFS samples

\begin{tabular}{|l|c|c|c|}
\hline Component & Natural [\%] & Tap water [\%] & Sea water [\%] \\
\hline Brucide & - & - & 3.9 \\
\hline Calcite & - & - & 67.7 \\
\hline Calcium carbonate & 29.1 & 35.1 & - \\
\hline Carbon dioxide Iv & - & 1.8 & 12.9 \\
\hline Carbon oxide (3/2) & 12.4 & - & - \\
\hline Enstatite & - & 25.5 & - \\
\hline Magnesioferrite & - & 8.6 & - \\
\hline Magnetite & 1.2 & - & - \\
\hline Nickel dimanganese (III) oxide & 6.2 & - & - \\
\hline Orthopyroxene & 31.6 & - & - \\
\hline Quartz low & 8.1 & - & - \\
\hline Silicon oxide alpha & - & - & 15.5 \\
\hline Vaterite & 11.4 & 29 & - \\
\hline
\end{tabular}

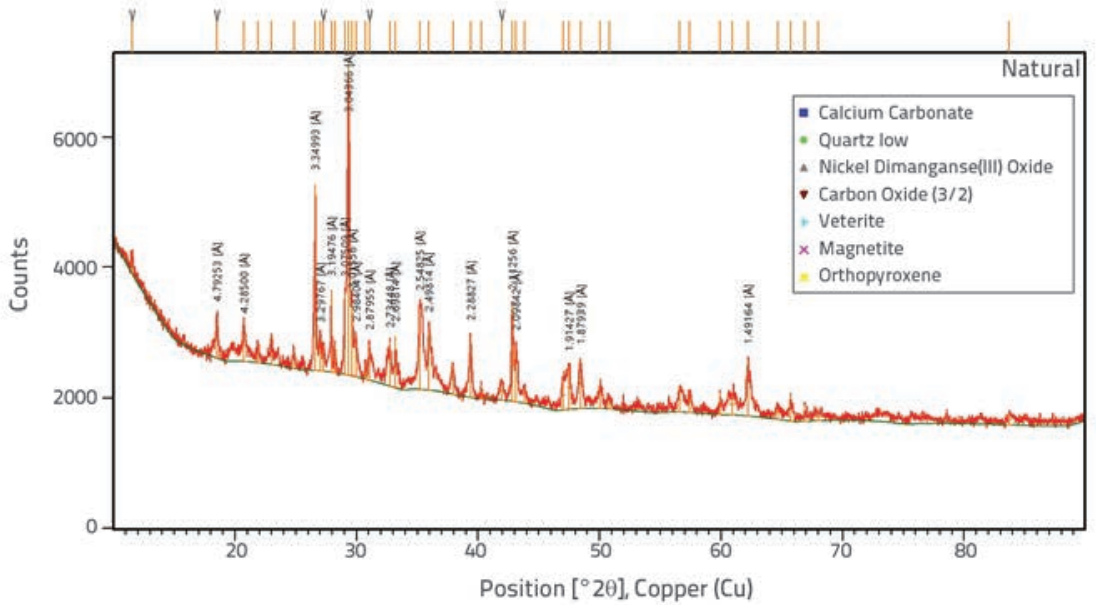

CBR curves for samples prepared at optimum moisture content with tap water are shown in Figure 8. The CBR tests were performed after samples had been cured for 96 hours. The cured CBR test results show the bearing capacity of materials, which is dependent on soil arrangement (density) and inter-particle forces (particle strength, matric suction, and dilatancy) $[20,21]$.

CBR values of samples prepared with tap water corresponding to the $0.2^{\prime \prime}$ $(5.08 \mathrm{~mm})$ penetration for all conditions are shown in Figure 9.

Figure 7. XRD spectra of natural BFS sample

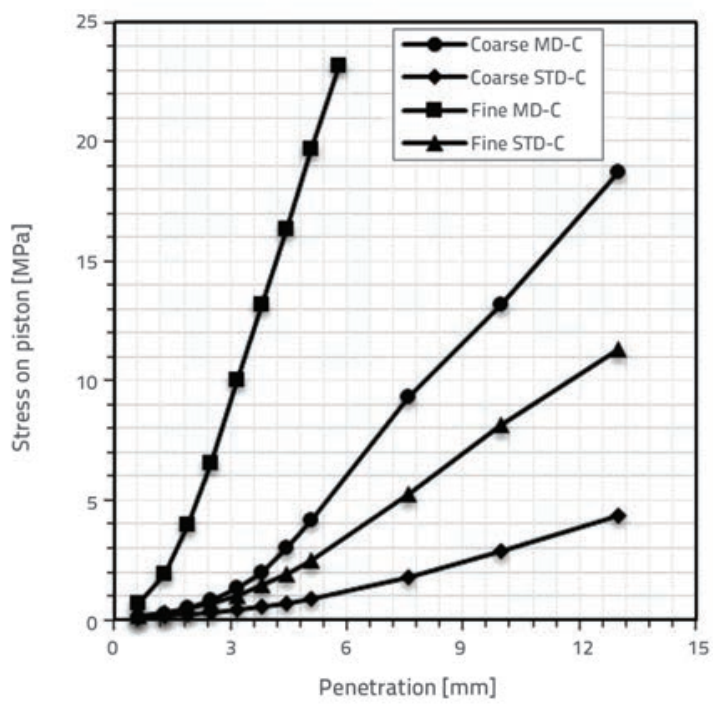

Figure 8. CBR curves of cured samples prepared with tap water

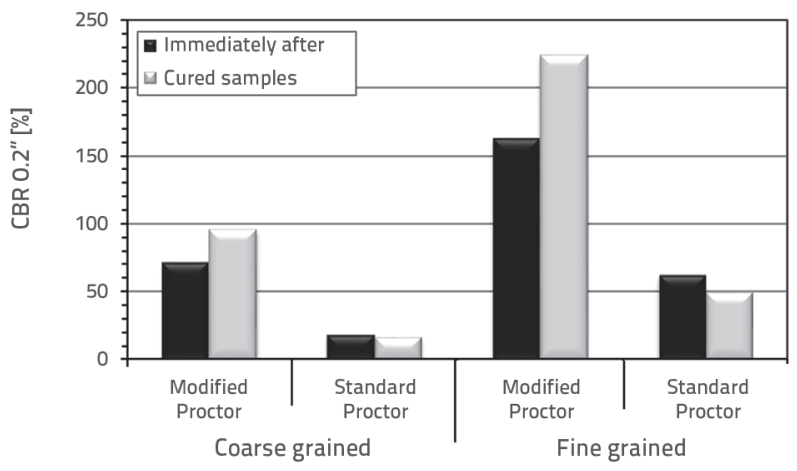

Figure 9. CBR values of samples prepared with tap water for different engineering properties

Figure 9 shows that fine grained samples have higher CBR values than coarse grained samples, with both standard and modified compaction energies. Fine grained samples have a lower void ratios and they are more tight structured compared to coarse grained samples. Higher compression energy ensured 
firmer structure of BFS samples. Thus, higher CBR values were observed for samples prepared with modified compaction energy. This situation is due to the fact that the Modified Proctor test has 4.5 times higher compaction energy than the Standard Proctor. The samples tested immediately after had higher CBR values than samples cured for Standard Proctor compaction. Because of the smearing effect, pore water reduces the friction between particles and decreases the bearing capacity. When the CBR values were evaluated for samples prepared with modified compaction energy, it was seen that higher values were exhibited by cured samples. As the void ratio and hydraulic conductivity decreased, pore water was trapped between the pores and then the extra pore fluid resistance was generated for samples compacted with modified energy.

CBR curves for samples prepared at optimum moisture content with sea water are shown in Figure 10. The CBR tests were conducted immediately after sample preparation.

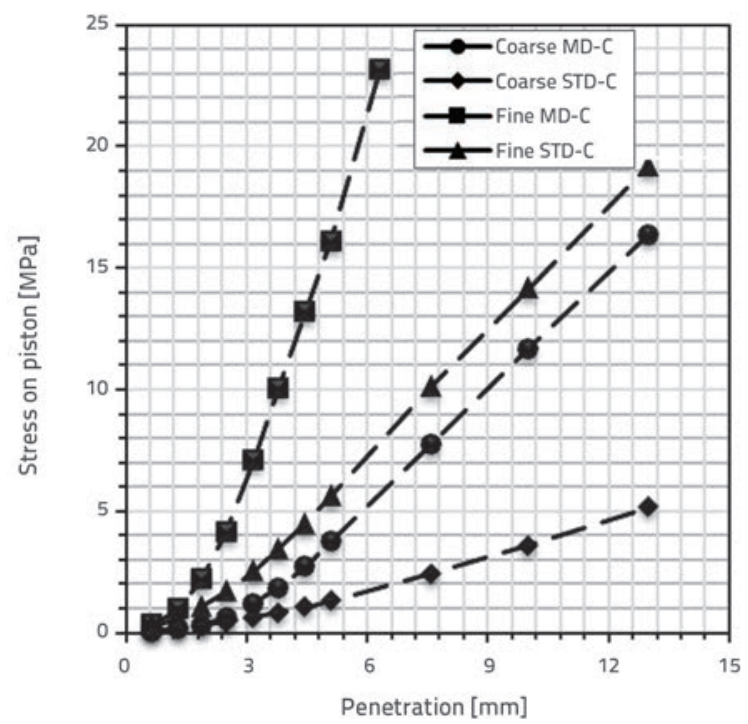

Figure 10. CBR curves of samples prepared with sea water at optimum moisture content

CBR values of samples prepared with sea water corresponding to the $0.2^{\prime \prime}(5.08 \mathrm{~mm})$ penetration for various conditions are presented in Figure 11.

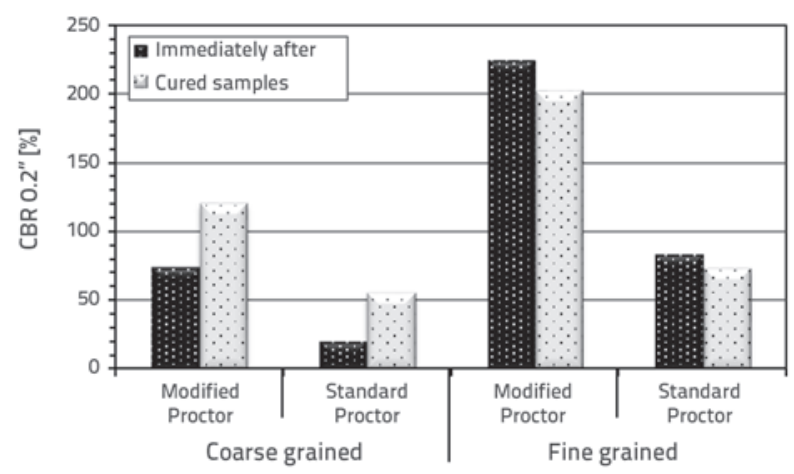

Figure 11. CBR values of samples prepared with sea water for different engineering properties
Figure 11 shows that fine grained samples which were tested immediately had higher CBR values than cured samples, for both Standard and Modified Proctor energy. On the contrary, coarse grained cured samples had higher CBR values than samples tested immediately for both Standard and Modified Proctor energy. Test results show that the sample compacted with Modified compaction energy has a considerably higher CBR value compared to the sample compacted with standard compaction energy. CBR values of samples prepared with sea and tap water were compared in order to investigate the pore fluid effect on the bearing capacity performance of BFS (Figure 12).

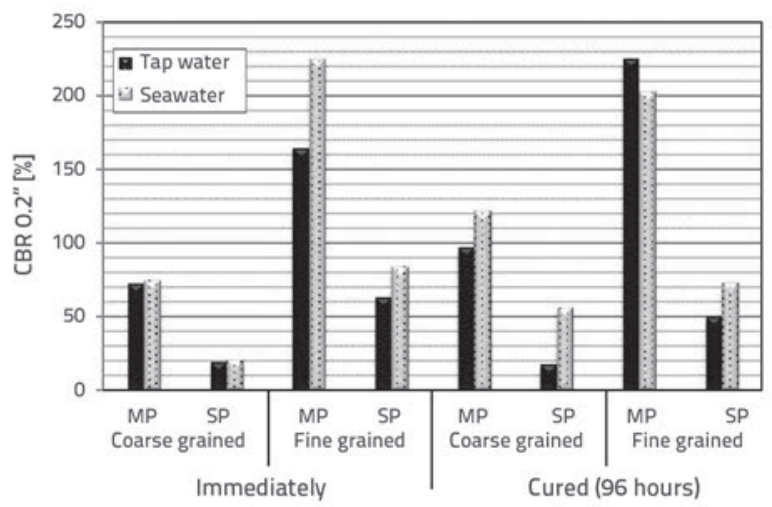

Figure 12. CBR values of fine and coarse grained samples prepared with tap and sea water

When compared to tap water, sea water affects the bearing capacity performance more positively as pore fluid for fine grained samples. Figure 12 shows that samples prepared with sea water have higher CBR values than samples prepared with tap water for both Standard Proctor and Modified Proctor energy. Positive effects of seawater on bearing capacity performance were more pronounced for fine grained samples when compared to coarse grained samples. The fine grained sample that has a much larger grain surface area than the coarse grained sample is considered to be in a good chemical relationship with sea water.

Figure 12 shows that coarse grained samples prepared with sea water have higher CBR values than samples prepared with tap water for both Standard Proctor and Modified Proctor energy. Fine grained samples prepared with sea water have higher CBR values than samples prepared with tap water for Standard Proctor energy. On the contrary, a higher value was observed for the sample compacted with modified energy.

In fact, two fine grained samples compacted with modified energy exhibit the highest CBR value. These two fine grained samples were prepared at an optimum water content and were compacted with modified compaction energy. One of the two highest CBR values was obtained with tap water, tested after curing period, and the other was obtained with sea water, tested immediately.

The test results reveal that BFS samples mixed with seawater exhibit higher CBR values. This was confirmed by XRD results. 
It was determined that samples prepared and cured with sea water have a high calcite content, which increases the bearing capacity. Similar results were also observed and reported by other researchers [33].

Bearing capacity values of immediately tested BFS samples prepared with tap and sea water are shown in Figure 13.

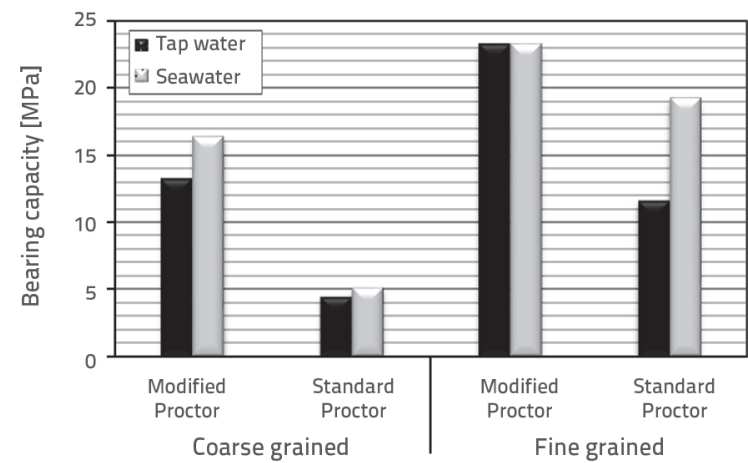

Figure 13. Bearing capacities of immediately tested samples prepared with sea and tap water

Figure 13 shows that samples prepared with sea water have higher bearing capacities than the samples prepared with tap water for both Standard Proctor and Modified Proctor energy. Only fine grained samples prepared with sea water exhibit an equal bearing capacity when prepared with tap water. This is due to the fact that the laboratory CBR apparatus reached its maximum capacity ( $45 \mathrm{kN}$ ) and tests were terminated. It can clearly be seen that samples prepared and cured with sea water have higher bearing capacity values.

Bearing capacities of BFS samples prepared and cured with tap and sea water are shown in Figure 14.

Figure 14 shows that samples prepared with sea water have higher bearing capacities than samples prepared with tap water for both Standard Proctor and Modified Proctor energy. Fine grained samples prepared with tap and sea water have equal bearing capacity because the apparatus has reached its maximum capacity (45 kN).

Engineering materials have been classified according to CBR value for various applications. Table 5 shows relations between the CBR value, soil properties, and application area. According to the unified soil classification system (USCS), fine and coarse grained BFS material was classified as well graded sand (SW). These two materials, with different grading, comply with conditions for use in subgrade and foundation fill layers.

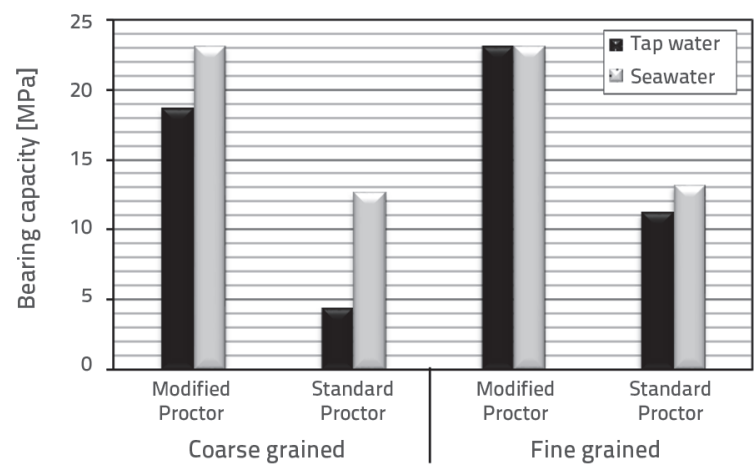

Figure 14. Bearing capacities of samples prepared and cured with sea and tap water

\section{Conclusion}

Geotechnical factors affecting bearing capacity of BFS were analysed in this study. Geotechnical engineering properties of BFS were investigated and then CBR tests were conducted on the fine and coarse grained BFS samples. The CBR test samples were prepared with tap and sea water and compacted with standard and modified compaction energies. Samples were examined in two parts; the first CBR sample was prepared at an optimum moisture content and then tested immediately. The second CBR sample was also prepared at an optimum moisture content and tested after the curing time of 96 hours.

- Test results show that CBR results are mostly influenced by compaction energy. The results show that the samples compacted with the modified compaction energy have at least 2.2 times higher CBR value than the samples compacted with the standard compaction energy.

- Grain size distribution is the second most effective parameter with regard to CBR values. Thus, fine grained BFS samples have at least 1.3 times higher CBR values than coarse grained samples. The BFS samples mixed with seawater have higher CBR values. This condition is additionally confirmed with $\mathrm{XRD}$ results. It was determined that the samples prepared and cured with sea water have high calcite content, which increases the bearing capacity.

Table 5. Engineering function of materials according to CBR value

\begin{tabular}{|c|c|c|c|c|}
\hline \multicolumn{2}{|c|}{ Soil properties and areas of usage } & \multicolumn{2}{c|}{ Classification system } \\
\hline CBR No. & General Evaluation & Function & USCS & AASHTO \\
\hline $0-3$ & Very poor & Base & $\mathrm{OH}, \mathrm{CH}, \mathrm{MH}, \mathrm{OL}, \mathrm{CH}, \mathrm{MH}, \mathrm{OL}$ & $\mathrm{A} 4, \mathrm{~A} 5, \mathrm{~A} 6, \mathrm{~A} 7$ \\
\hline $3-7$ & Poor & Base & $\mathrm{OL}, \mathrm{CL}, \mathrm{ML}, \mathrm{SC}, \mathrm{SM}, \mathrm{SP}$ & $\mathrm{A} 2, \mathrm{~A} 4, \mathrm{~A}, \mathrm{~A} 7$ \\
\hline $7-20$ & Medium & Subgrade & $\mathrm{GM}, \mathrm{GC}, \mathrm{SW}, \mathrm{SM}, \mathrm{SP}, \mathrm{GP}$ & $\mathrm{A} 1 \mathrm{~b}, \mathrm{A2}-5, \mathrm{~A}-3, \mathrm{~A} 2-6$ \\
\hline $20-50$ & Well & Foundation or subgrade & $\mathrm{GW}, \mathrm{GM}$ & $\mathrm{A} 1 \mathrm{a}, \mathrm{A2}-4, \mathrm{~A} 3$ \\
\hline$>50$ & Very well & Foundation & & \\
\hline
\end{tabular}


- When average CBR values were compared to one another, it was established that the samples prepared and cured with sea water have higher values compared to other samples $\left(\mathrm{CBR}_{\text {sea }}=107.1>\mathrm{CBR}_{\text {tap }}=88.2\right)$.

- No clear relation was established between the curing period and CBR values of BFS samples. Cured samples compacted with modified energy generally have higher CBR values. On the other hand, immediately tested samples compacted with standard energy usually have higher CBR values.

- It was clearly seen that BFS has appropriate mechanical properties and that it can be used for numerous engineering applications as fill material.

\section{REFERENCES}

[1] Ekincioglu, O., Gurgun, A.P., Engin, Y., Tarhan, M., Kumbaracibas, S.: Approaches for sustainable cement production-A case study from Turkey, Energy and Buildings, 66 (2013), pp. 136-142, doi: https:// doi.org/10.1016/j.enbuild.2013.07.006.

[2] Ramani, P.V., Chinnaraj, P.K.: Geopolymer concrete with ground granulated blast furnace slag and black rice husk ash, GRAĐEVINAR, 67 (2015) 8, pp. 741-748, doi: https://doi. org/10.14256/JCE.1208.2015.

[3] Luga, E., Atis, C.D., Karahan, O., Ilkentapar, S., Bahsude Gorur, E.: Strength properties of slag/fly ash blends activated with sodium metasilicate, GRAĐEVINAR, 69 (2017) 3, pp. 199-205, doi: https:// doi.org/10.14256/JCE.1468.2015.

[4] Martin, P.E., Bobillon, G., Eisenlohr, L.: Reuse of solid waste from the clearing of road basins and ditches in civil engineering: from characterization to ways of treatment. Houille BlancheRevue Internationale De L'Eau, 17 (2008), pp. 130-136, DOI : 10.1007/978-90-481-3043-6-21.

[5] Zhang, L.: Production of bricks from waste materials-A review. Construction and Building Materials, 47 (2013), pp. 643-655, DOI: 10.1016/j.conbuildmat.2013.05.043.

[6] Kodikara, J., Yeo, R.: Performance Evaluation of Road Pavements Stabilised In Situ. Elsevier Geo-Engıneering Book Series, 3 (2005), doi: 10.1016/S1571-9960(05)80018-7.

[7] O'Kelly, B.C.: Geo-engineering properties of granulated blast furnace slag. Proceedings, Innovative Geotechnical Engineering, International Conference on Geotechnical Engineering, Tunis, Tunisia, 24-26 March, 2008, pp. 249-257.

[8] Poh, H., Ghataora, G., Ghazireh, N.: Soil Stabilization Using Basic Oxygen Steel Slag Fines. J. Mater. Civ. Eng., 18 (2006) 2, pp. 229-240, doi: https://doi.org/10.1061/(ASCE)08991561(2006)18:2(229).

[9] Yao, A.L., Sun, Z.J.: The Research on Slag Road Cement (SRC) Using Less Clinker and More Granulated Blast Furnace Slag. Proceedings of the $5^{\text {th }}$ China-Japan Workshop on Pavement Technologies, 2009, pp. 100-107.

[10] Yazıcı, V.: Stabilization of expansive clays using granulated blast furnace slag (GBFS), GBFS-lime combinations and GBFS cement. Post Graduate thesis. Middle East Technıcal University, (2004).

[11] Buddhdev, B.G., Varia, H.R.: Feasibility Study on Application of Blast Furnace Slag in Pavement Concrete. International Journal of Innovative Research in Science, Engineering and Technology, 3 (2014) 3, pp. 10795-10802, ISSN: 2319-8753.
It is however recommended to further examine BFS material with regard to its environmental properties in order to avoid any adverse effects.

\section{Acknowledgements}

The authors greatly acknowledge the support of Özerdem Demir Contracting Construction Marketing Industry and Trade Limited Company with regard to supply of materials needed for this study.

[12] Cokca, E., Yazici, V., Ozaydin, V.: Stabilization of Expansive Clays Using Granulated Blast Furnace Slag (GBFS) and GBFS-Cement. Geotech. Geol. Eng., 27 (2009), pp. 489-499, DOI: 10.1007/ s10706-008-9250-z.

[13] Sivrikaya, O., Yavascan, S., Cecen, E.: Effects of ground granulated blast-furnace slag on the index and compaction parameters of clayey soils, Acta Geotechnica Slovenica, (2014), pp. 19-27, 2014/1.

[14] Sivakumar, V., Tan, W., Graham, J.: CBR, undrained strength and yielding characteristics of compacted tills. 3rd international conference on unsaturated soils, CRC Press, 2 (2002), pp. 663668.

[15] Vogrig, M., Macdonald, A., Vanapalli, S., Siekmeier, J., Roberson, R., Garven, E.: A laboratory technique for estimating the resilient modulus of unsaturated soil specimens from CBR and unconfined compression tests. 56th Canadian geotechnical conference, (2003), pp. 99-106, Winnipeg.

[16] Ampadu, S.: A laboratory investigation into the effect of water content on the CBR of a subgrade soil. In T. Schanz (Ed.), Experimental Unsaturated Soil Mechanics, 112 (2007), pp. 137144, DOI: 10.1007/3-540-69873-6-12.

[17] Purwana, Y., Nikraz, H., Jitsangiam, P.: Experimental study of suction-monitored CBR test on sand-kaolin clay mixture. International Journal of Geomaterials, 3 (2012) 2, pp. 419-422, DOI: 10.21660/2012.6.39.

[18] Singh, S., Sharan, A.: Strength characteristics of compacted pond ash. Geomechanics and Geoengineering: An International Journal, 9 (2014) 1, pp. 9-17, DOI:10.1080/17486025.2013.772661.

[19] Mirzaii, A., Negahban, M.: California bearing ratio of an unsaturated deformable pavement material along drying and wetting paths. Road Materials and Pavement Design, 17 (2016) 1, 261-269, doi: https://doi.org/10.1080/14680629.2015.1067247.

[20] Head, K.H.: Manual of soil laboratory testing (Vol. 2): permeability, shear strength and compressibility tests. $2^{\text {nd }}$ ed. London: Pentech Press, 1994.

[21] Arulrajah, A., Disfani, M.M., Horpibulsuk, S., Suksiripattanapong, C., Prongmanee, N.: Physical properties and shear strength responses of recycled construction and demolition materials in unbound pavement base/subbase applications. Construction and Building Materials, 58 (2014), pp. 245-257, doi: https://doi. org/10.1016/j.conbuildmat.2014.02.025. 
[22] Jiao, T., Hu, L., Zhou, J., Fu, J.: Test on cement stabilized blast furnace slag material. Advanced Materials Research, 671-674 (2013), pp. 1297-1300, doi: https://doi.org/10.4028/www.scientific.net/ AMR.671-674.1297

[23] ASTM D422-63e2. Standard Test Method for Particle-Size Analysis of Soils, ASTM International, (2007), West Conshohocken, PA, www.astm.org.

[24] ASTM D4318-10e1. Standard Test Methods for Liquid Limit Plastic Limit, and Plasticity Index of Soils, ASTM International, (2010), West Conshohocken, PA, www.astm.org

[25] ASTM D2487-11. Standard Practice for Classification of Soils for Engineering Purposes (Unified Soil Classification System), ASTM International, (2011), West Conshohocken, PA, www.astm.org.

[26] ASTM D854-14. Standard Test Methods for Specific Gravity of Soil Solids by Water Pycnometer, ASTM International, (2014), West Conshohocken, PA, www.astm.org.

[27] Kocasoy, G.: Atıksu arıtma çamuru ve katı atık ve compost örneklerinin analiz yöntemleri. (1994), ISBN-13: 978-975-518083-0, ISBN: 975-518-083-4.
[28] ASTM D698-12e2. Standard Test Methods for Laboratory Compaction Characteristics of Soil Using Standard Effort (12 $\left.400 \mathrm{ft}-\mathrm{lbf} / \mathrm{ft} 3\left(600 \mathrm{kN}-\mathrm{m} / \mathrm{m}^{3}\right)\right)$, ASTM International, (2012), West Conshohocken, PA, www.astm.org.

[29] ASTM D1557-12e1. Standard Test Methods for Laboratory Compaction Characteristics of Soil Using Modified Effort (56000 $\left.\mathrm{ft}-\mathrm{lbf} / \mathrm{ft} 3\left(2700 \mathrm{kN}-\mathrm{m} / \mathrm{m}^{3}\right)\right)$, ASTM International, (2012), West Conshohocken, PA, www.astm.org.

[30] ASTM D1883-16. Standard Test Method for California Bearing Ratio (CBR) of Laboratory-Compacted Soils. ASTM International, (2016), West Conshohocken, PA, www.astm.org.

[31] ASTM D6913-04e1. Standard Test Methods for Particle-Size Distribution (Gradation) of Soils Using Sieve Analysis. ASTM International, (2009), West Conshohocken, PA, www.astm.org.

[32] Keir, R.S.: The dissolution kinetics of biogenic calcium carbonates in seawater Geochimica et Cosmochimica Acta, 44 (1980), pp. 241-252, doi: https://doi.org/10.1016/0016-7037(80)90135-0.

[33] Sharma, A., Ramkrishnan R.: Study on effect of Microbial Induced Calcite Precipitates on strength of fine grained soils. Perspectives in Science, 8 (2016), pp. 198-202, doi: https://doi.org/10.1016/j. pisc.2016.03.017 